\title{
Bioprospecting Studies of Halophilic Bacteria - Streptomyces sp MA05 and Halobacterium sp MA06
}

\author{
Antony V Samrot ${ }^{1, *}$ (D), Divya $R^{2}$, Narendrakumar $G^{2}$, Abirami $S^{3}$, Dhiva $S^{4}$, Prakash $P^{2}$, Jane Cypriyana \\ P J ${ }^{2}$, Padmanaban $S^{5}$ \\ 1 Department of Biomedical Sciences, Faculty of Medicine and Biomedical Sciences, Bandar Saujana Putra, 42610 \\ Jenjarom, Selangor, Malaysia \\ 2 Department of Biotechnology, Sathyabama Institute of Science and Technology (Deemed to be University), Jeppiaar \\ Nagar, Rajiv Gandhi Salai, Chennai - 600 119. Tamil Nadu, India \\ 3 Department of Microbiology, Kamaraj College of Arts and Science, Thoothukudi, Tamil Nadu, India \\ 4 Department of Microbiology, Sree Narayana College, Alathur, Palakkad, Kerala - 678682 \\ 5 Department of Medical Nanotechnology, Sastra University, Thanjavur, Tamil Nadu - 613401, India \\ * Correspondence: antonysamrot@gmail.com;
}

Scopus Author ID 36100751800

Received: 15.07.2020; Revised: 14.08.2020; Accepted: 16.08.2020; Published: 19.08.2020

\begin{abstract}
In this study, two halophiles (Halobacterium sp MA06 and Streptomyces sp MA05) isolated from the salt lake of Chennai were exploited. Optimization of growth condition for both the organisms was done and then subjected for bioprospecting analysis for the enzyme (amylase) and pigment production. One of the isolates, i.e., Streptomyces sp MA05, was found to produce amylase. Thus that organism was subjected to amylase production, and the produced amylase was characterized. The other isolate (Halobacterium sp MA06) was found to produce orange color pigment, and the pigment was characterized by GC-MS analysis and subjected to optimization of pigment production. The extract of Streptomyces sp MA05 and pigment of Halobacterium sp MA06 were subjected to antimicrobial and anticancer activity. Only the metabolite of Streptomyces sp MA05 had antibacterial activity.
\end{abstract}

Keywords: Bioprospecting; amylase production; pigment production.

(C) 2020 by the authors. This article is an open-access article distributed under the terms and conditions of the Creative Commons Attribution (CC BY) license (https://creativecommons.org/licenses/by/4.0/).

\section{Introduction}

Bioprospecting organisms from any source are very important, as the obtained products have industrial and medicinal applications [1,2]. Marine organisms have been showing more bioactivities [3,4]. Hypersaline environments such as the sea, lake, estuarine have a notable number of halophilic bacteria and halotolerant bacteria [5,6]. In recent decades, microbes isolated from these hypersaline environments and surroundings are highly explored for many products $[7,8]$. These halophilic prokaryotes are classified on the basis of the salt requirement for survival and growth as follows - slightly halophiles (1 - 3\% salt), moderate halophiles (3 $-15 \%$ salt $)$, and extremely halophiles $(15-32 \%$ salt $)[9,10]$. These halophiles are widespread and abundant in salt lakes, sea, etc. Since they live in extreme conditions, they could synthesize several metabolites and produce useful enzymes, including amylase, esterase, cellulase, protease, etc. [11-14]. These organisms also have a vital role in heavy oil degradation [15], biofuel production, and polyaromatic hydrocarbon production [16]. Metabolites of halophilic isolates from invertebrates were reported to be efficient against various pathogenic bacteria [17-19]. Halophilic Vibrio sp. A1SM3-36-8, was reported to have good antibacterial and 
anticancer activity [20]. Pigments derived from halophilic bacteria like $\beta$ carotene and bacteriorhodopsin have shown many applications in optical mechanics [21-23]. Having known the potency of these halophiles, this study was done to optimize the growth condition of two halophiles isolated from Salt lake, Chennai. One of the organisms was producing orange pigment, and the other was a chalky white colony that was producing amylase enzymes. Pigment and the extract of the organisms were tested for various bioactivity studies.

\section{Materials and Methods}

\subsection{Chemicals used and selection of halophilic microorganisms.}

All the chemicals were bought from HiMedia, India. Seawater was collected from Kovalam, Chennai, Tamil Nadu, India. Two organisms isolated from the water sample collected from the Salt Lake, Muttukadu, Chennai were used in this study. One was orange pigment-producing organism - Halobacterium sp MA06 (Genbank Accession no. MN626450), and the other was chalky white colony-forming organism - Streptomyces sp MA05 (Genbank Accession no. MN629934).

\subsection{Optimization study.}

\subsubsection{Growth optimization.}

Both the organisms were subjected to grow on halophilic isolation medium (For 1000 $\mathrm{mL}$ : Casein powder $-1 \mathrm{~g}$, peptone $-0.5 \mathrm{~g}$, Trisodium citrate $-0.3 \mathrm{~g}$, Yeast extract $-1 \mathrm{~g}$, Potassium chloride $-0.2 \mathrm{~g}$, Magnesium sulphate $-2.5 \mathrm{~g}$, Sodium chloride $-25 \mathrm{~g}$ ), Seawater medium (seawater $+2 \%$ Agar), Seawater with $1 \%$ yeast extract $+1 \%$ peptone $+2 \%$ Agar, Seawater with $1 \%$ yeast extract $+1 \%$ peptone $+1 \%$ trisodium citrate $+1 \% \mathrm{KCl}+1 \% \mathrm{MgSO}_{4}$ $+2 \%$ Agar. $\mathrm{pH}$ was set as 5 in all the mediums. The organism was inoculated onto the medium and incubated for $48-72 \mathrm{~h}$. The medium which influenced the growth of the organism was used further. The growth pattern was analyzed by its growth on medium with $2 \%$ agar. The above parameters were even checked by Manikandan et al. (2009) [24]. The medium was further optimized for $\mathrm{NaCl}$ concentration. After standardizing the $\mathrm{NaCl}$, the medium was subjected to the standardization of optimal $\mathrm{MgSO}_{4}$ concentration, $\mathrm{pH}$, etc.

\subsection{Optimization and characterization of pigment.}

\subsubsection{Pigment production optimization.}

The pigmenting organism was allowed to grow on halophilic isolation medium (with $2 \%$ Agar) with varied concentrations of sodium chloride, peptone, and yeast extract.

\subsubsection{Extraction of pigment.}

Orange pigment organism was grown as stated earlier. Colonies were scraped out of the plate using an inoculation loop and immediately transferred to $<3 \% \mathrm{NaCl}$ solution. The solution was subjected to centrifugation at $10000 \mathrm{rpm}$ for $30 \mathrm{~min}$ [25]. The pellet was weighed, and the wet mass was identified. The cell was lysed by adding the pellet with distilled water (1:50) and kept at $4{ }^{\circ} \mathrm{C}$ for $24 \mathrm{~h}$. It was then centrifuged at $10000 \mathrm{rpm}$ for $30 \mathrm{~min}$, and the pellet was collected. Pigment extraction was done by adding 90\% acetone in the ratio of 1:5 to the pelletized lysed cells [26]. The supernatant (acetone) containing the pigment was collected by 
centrifugation. Acetone was evaporated out in the fume hood, and the pigment weight was measured. The percentage of pigment production was obtained as described [27].

\subsubsection{Characterization of pigment.}

The pigment was characterized by GC-MS analysis (Clarus 680, Perkin Elmer1). Where the Initial temperature in the oven was $60^{\circ} \mathrm{C}$ for $2 \mathrm{~min}$, ramp temperature was increasing at $10^{\circ} \mathrm{C} / \mathrm{min}$ to $300^{\circ} \mathrm{C}$ with a hold of $6 \mathrm{~min}$. The total run time was $32 \mathrm{~min}$. Injector temperature was $250{ }^{\circ} \mathrm{C}$, with a volume of $1 \mu \mathrm{L}$. Flow Rate was set as $1 \mathrm{~mL} / \mathrm{min}$, and the carrier gas used was helium, and the column used was Elite-5MS (30.0m, 0.25mmID, $250 \mu \mathrm{m} \mathrm{df})$.

\subsection{Amylase production.}

\subsubsection{Qualitative analysis of amylase production.}

Media Composition used was as designated in previous studies [27], where the $\mathrm{NaCl}$ concentration alone was increased to $10 \mathrm{~g} / 100 \mathrm{~mL}$. Isolated colonies were streaked on the plate and incubated for $72 \mathrm{~h}$ at room temperature. After incubation, the iodine solution was flooded and analyzed for the formation of a clearance zone.

\subsubsection{Optimization of amylase production.}

Enzyme production media Composition was as follows where $\mathrm{NaCl}$ concentration was added as $100 \mathrm{~g} / \mathrm{L}$ other chemicals are as follows $(\mathrm{g} / \mathrm{L})$ Citric acid - 0.42, Yeast extract - 2.5, $\mathrm{MgCl}_{2} .6 \mathrm{H}_{2} \mathrm{O}-0.25, \mathrm{MnCl}_{2} .4 \mathrm{H}_{2} \mathrm{O}-1.0 \times 10^{-2}, \mathrm{CaCl}_{2}-2.2 \times 10^{-3}, \mathrm{FeCl}_{3} .6 \mathrm{H}_{2} \mathrm{O}-2.7 \times 10^{-2}$, $\mathrm{CuCl}_{2} .2 \mathrm{H}_{2} \mathrm{O}-8.5 \times 10^{-4}$, Soluble starch $-5 \mathrm{~g}, \mathrm{pH}-7.1 \mathrm{~mL}$ culture (which was grown in the above-mentioned media) was inoculated to the $100 \mathrm{~mL}$ above medium and incubated at $37{ }^{\circ} \mathrm{C}$. After $48 \mathrm{~h}$ of incubation, the media was centrifuged at $10000 \mathrm{rpm}$, and the supernatant was taken as a crude enzyme source as described [28]. The activity of amylase was done as follows $-500 \mu \mathrm{L}$ of $1 \%$ soluble starch in PBS buffer ( $\mathrm{pH}$ 6.5) was added with $300 \mu \mathrm{L}$ crude enzyme source and incubated at $37{ }^{\circ} \mathrm{C}$ for $15 \mathrm{~min}$. Following that, it was added with $1 \mathrm{~mL}$ DNS reagent. Using spectrometry, reducing sugars released was assayed, and the enzyme unit was demarcated, as described earlier [29]. Optimization of amylase production was done for substrate concentration 0.2 to $1 \mathrm{~g}$, temperature range $25-45^{\circ} \mathrm{C}$, time interval $24-120 \mathrm{~h}$, and pH 4 - 8.

\subsubsection{Amylase characterization.}

The role of $\mathrm{pH}$ and temperature on amylase activity was done [30] by subjecting the isolated enzymes for its activity in different $\mathrm{pH}$ and temperature. Amylase activity was analyzed, as mentioned earlier in this study, as well as earlier studies [31].

\subsection{Antimicrobial susceptibility study.}

\subsubsection{Extraction of antimicrobial metabolites}

The culture filtrate was added with chloroform (1:1). It was taken in separating funnel and shaken vigorously for $2-5 \mathrm{~min}$. Then the solution was allowed to stand; still, the organic phase was collected, and it was evaporated in a fume hood. 


\subsubsection{Agar well diffusion method.}

The antibacterial activity of the above extract and pigment was performed against Staphylococcus aureus and Escherichia coli [32]. The required concentration of extract/pigment was dissolved in Dimethyl sulfoxide (DMSO) and used for the study. Antibiotic disc - Gentamycin (200 mcg) and amoxicillin (200 mcg) was used a positive control. The plate was incubated at $37{ }^{\circ} \mathrm{C}$ for $24 \mathrm{~h}$.

\subsection{Anticancer activity - MTT assay.}

Vero and Hep G2 cell lines were obtained from NCCS, Pune, which was maintained in MEM with $10 \%$ serum. Streptomyces sp MA05 extract and pigment were subjected to MTT assay as described by Mosman (1983) [33]. Each cell line was seeded with 10,000 cells onto a 96 well plate and incubated at $37{ }^{\circ} \mathrm{C}$ till it reached the confluency in the $\mathrm{CO}_{2}$ incubator. Plates were washed with PBS and introduced with different concentrations $(0.3125,0.625,1.25$, and $2.5 \mu \mathrm{g}$ ) of either the Streptomyces sp MA05 extract or pigment as triplicates. It was incubated and added with $100 \mu \mathrm{L}$ MTT (5mg / mL) and kept in the dark for $4-5 \mathrm{~h}$, following that 100 $\mu \mathrm{L}$ DMSO was added and read at $570 \mathrm{~nm}$. The mortality percentage was calculated.

\subsection{Statistical analysis.}

All the experiments had been carried thrice, and all the results are given as mean \pm standard deviation.

\section{Results and Discussion}

\subsection{Selection of halophilic microorganism.}

Following the isolation procedure for halophilic organisms, an orange pigmentproducing Halobacterium sp MA06 and rough, chalky white colonies forming Streptomyces sp MA05 were isolated from salt lake, Chennai (Figure 1). Preliminary morphological observation and Gram staining reaction revealed that pigmented bacteria were gram-negative rod, while white was gram-positive filamentous.
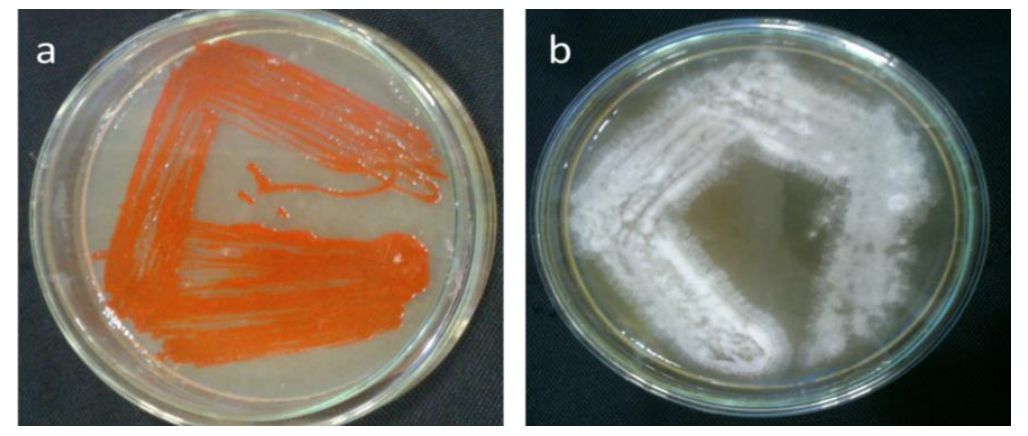

Figure 1. Organisms isolated from salt lake, Chennai a) Halobacterium sp MA06. b) Streptomyces sp MA06

\subsection{Optimization study.}

The organisms grew well on the halophilic isolation medium but failed to grow on the rest of the medium (Table 1). This was because of rest of the medium were lacking either nitrogen source or less concentration of $\mathrm{NaCl}$ concentration. 
Table 1. Growth characteristics of organisms in a different medium.

\begin{tabular}{l|c|c|c} 
Complex medium & $\mathbf{p H}$ & Bacteria & Streptomyces sp MA05 \\
\hline Halophilic isolation medium & 5 & ++ & ++ \\
\hline Seawater medium & 5 & $\mathrm{~N} / \mathrm{G}$ & $\mathrm{N} / \mathrm{G}$ \\
\hline $\begin{array}{l}\text { Sea water + yeast extract }+ \\
\text { peptone }\end{array}$ & 5 & $\mathrm{~N} / \mathrm{G}$ & $\mathrm{N} / \mathrm{G}$ \\
\hline $\begin{array}{l}\text { Sea water + yeast extract }+ \\
\text { peptone + tri-Na-citrate } \\
+\mathrm{KCl}+\mathrm{MgSO} 4\end{array}$ & 5 & $\mathrm{~N} / \mathrm{G}$ & $\mathrm{N} / \mathrm{G}$ \\
++- good growth, N/G - no growth & & \\
+
\end{tabular}

Table 2 shows the optimum $\mathrm{NaCl}$ concentration for the organism's growth in the halophilic isolation medium. The bacteria were found to grow well at $20 \%$ to $32 \% \mathrm{NaCl}$ concentration, whereas Streptomyces sp MA05 grew well at $10 \%$. The pigmented bacterium was found to be extreme halophilic as it grew well on $20 \% \mathrm{NaCl}$, only in the presence of magnesium, and the optimal $\mathrm{MgSO}_{4}$ concentration was found to be $2.5 \%$ (Table 3 and 4). Optimum $\mathrm{pH}$ for the pigmented bacteria was found to be 7 and for Streptomyces sp MA05 as 5 (Table 5). Our results were on par with Hongyu et al. (2009) and Roohi et al. (2012), where they found the isolated halophils to grow well at a temperature of $28-40{ }^{\circ} \mathrm{C}, \mathrm{pH} 7.0-9.0$ and $5-20 \%(\mathrm{w} / \mathrm{v}) \mathrm{NaCl}[34,35]$. Halophilic bacteria isolated from a salt mine in Central Anatolia (Turkey) grew best at $3.5-4.5 \mathrm{M} \mathrm{NaCl}$ concentration and $\mathrm{pH} 7$ - 7.5 [36]. Magnesium has a vital role in the bacteria growth, whereas the Streptomyces sp MA05 grew irrespective of magnesium. It was also found that the halophilic bacteria require magnesium, too, for their growth [37]. Mironescu et al. (2005) showed the influence of magnesium in halophilic microbe growth [38]. Whereas Alinei et al. (2006) also observed the same [39]. The difference is due to the influence of $\mathrm{Mg}^{2+}$, which has limiting action on the microorganisms.

Table 2. Growth characteristics of organisms in Halophilic Isolation Medium with varying $\mathrm{NaCl}$ concentration.

\begin{tabular}{l|c|c|c}
$\begin{array}{l}\text { NaCl } \\
\text { concentration }\end{array}$ & $\mathbf{p H}$ & Bacteria & Streptomyces sp MA05 \\
\hline $4 \%$ & 5 & N/G & + \\
\hline $10 \%$ & 5 & N/G & +++ \\
\hline $16 \%$ & 5 & + & ++ \\
\hline $20 \%$ & 5 & +++ & + \\
\hline $22 \%$ & 5 & +++ & + \\
\hline $25 \%$ & 5 & +++ & + \\
\hline $32 \%$ & 5 & +++ & N/G \\
resence of growth, ++- good growth, +++ - abundant growth, N/G - no growth
\end{tabular}

Table 3. Growth characteristics of organisms in Halophilic Isolation Medium with varying $\mathrm{NaCl} \& \mathrm{MgSO}_{4}$ concentration.

\begin{tabular}{l|c|c|c|c}
$\mathbf{N a C l}$ & $\mathbf{M g S O}_{4}$ & $\mathbf{p H}$ & Bacteria & Streptomyces sp MA05 \\
\hline $20 \%$ & - & 5 & $\mathrm{~N} / \mathrm{G}$ & + \\
\hline $20 \%$ & $2.5 \%$ & 5 & ++ & + \\
\hline $10 \%$ & - & 5 & $\mathrm{~N} / \mathrm{G}$ & ++ \\
\hline $10 \%$ & $2.5 \%$ & 5 & + & +++ \\
+- presence of growth, ++ - good growth, +++- abundant growth, N/G - no growth
\end{tabular}

Table 4. Growth characteristics of organisms in Halophilic Isolation Medium with varying $\mathrm{MgSO}_{4}$ concentration.

\begin{tabular}{l|c|c|c}
$\mathbf{M g S O}_{4}$ Concentration & $\mathbf{p H}$ & Bacteria & Streptomyces sp MA05 \\
\hline $1.5 \%$ & 5 & + & ++ \\
\hline $2.5 \%$ & 5 & ++ & ++ \\
\hline $3.5 \%$ & 5 & + & + \\
\hline $4.5 \%$ & 5 & $\mathrm{~N} / \mathrm{G}$ & $\mathrm{N} / \mathrm{G}$ \\
+- presence of growth, ++- good growth, N/G - no growth
\end{tabular}


Table 5. Growth characteristics of organisms in Halophilic Isolation Medium at varying pH.

\begin{tabular}{l|c|c}
$\mathbf{p H}$ & Bacteria & Streptomyces $\boldsymbol{s p}$ MA05 \\
\hline 4 & N/G & N/G \\
\hline 5 & ++ & +++ \\
\hline 7 & +++ & ++ \\
\hline 8 & ++ & N/G \\
\hline 10 & N/G & N/G
\end{tabular}

+ - presence of growth, ++ - good growth, +++ - abundant growth, N/G - no growth

In our study, the maximum pigment was produced from bacteria in the halophilic agar medium with $32 \% \mathrm{NaCl}$, i.e., $64 \%$ (Figure 2). Further, the maximum pigment (64\%) was produced at medium containing $10 \%$ yeast extract concentration and $15 \%$ peptone concentration (Figures 3 and 4). Pigment production by Halorubrum sodomense was reported to be maximum at $\mathrm{NaCl}$ concentration of $30 \%$ [40]. Salt concentration has a direct influence on pigment production [41].

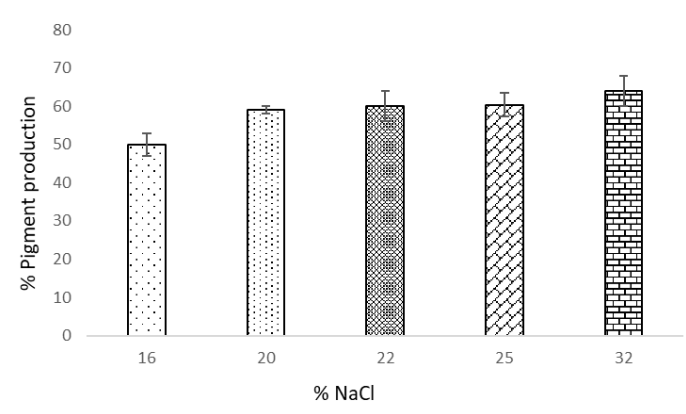

Figure 2. Pigment production in varied $\mathrm{NaCl}$ concentration.

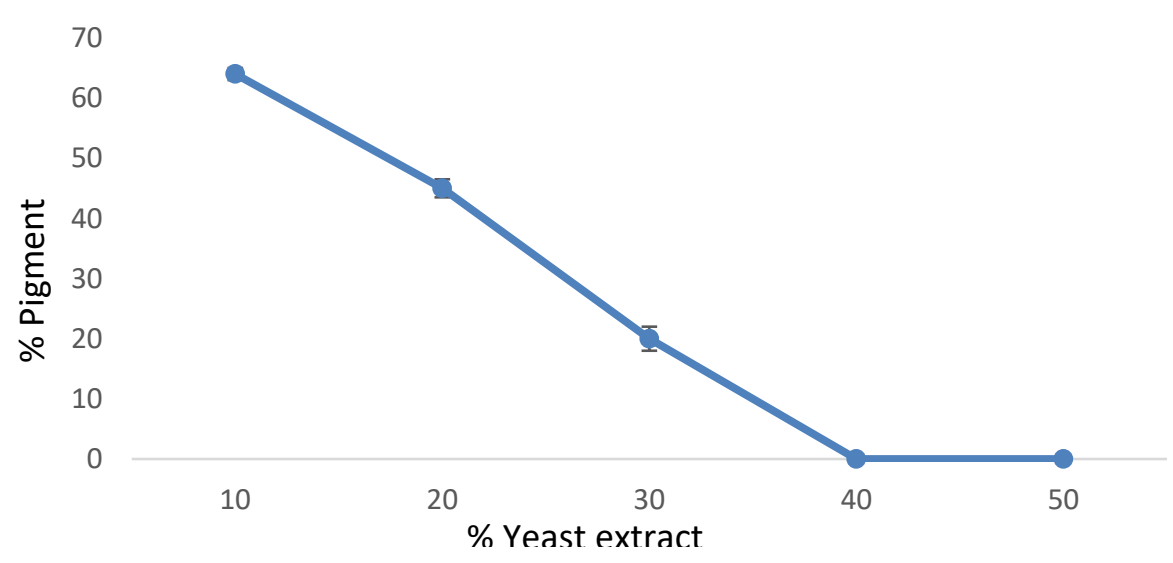

Figure 3. Pigment production in different yeast extract concentration.

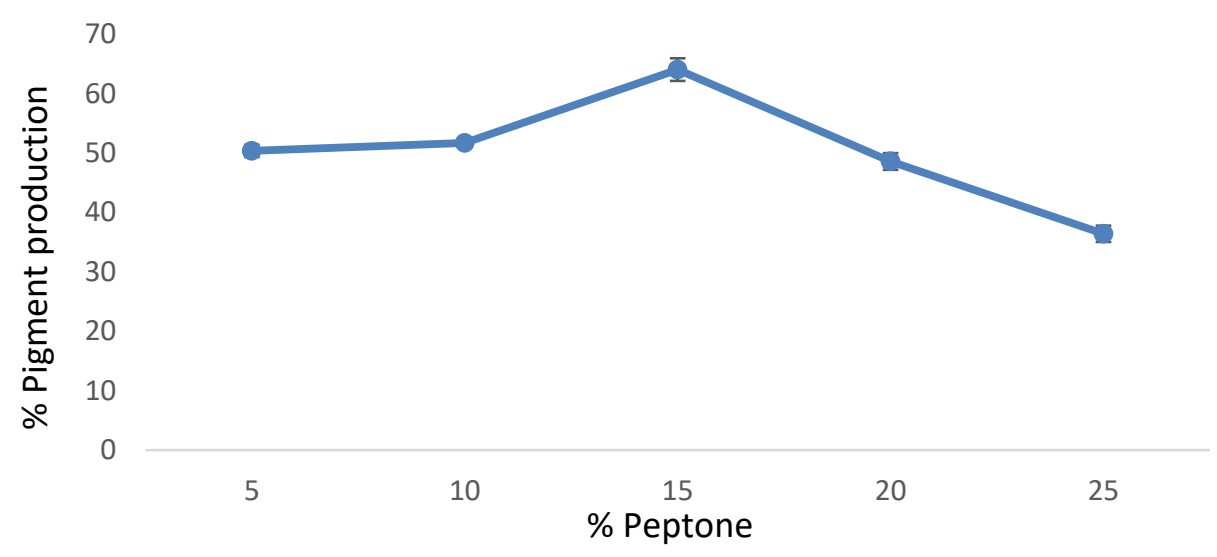

Figure 4. Pigment production in different peptone concentration. 


\subsection{GC-MS analysis.}

The abundant compound shows maximum peak at retention time of 23.06 and 13.3 (Figure 5), which stands for phenol,2,6-bis(1,1dimethylethyl-). Costantino et al (1993) found to that 2,6-bis-(1,1-dimethylethyl)phenol derivatives to have anti-inflammatory property [42]. Other compounds like 2-T-Butyl-5-chloromethyl-3-methyl-4-oxoimidazolidine-1-carboxylic acid - t-butyl ester (RT - 22.6 ), methyl 2-hydroxy-eicosanoate (RT -28.5), fumaric acid, 2,4dimethylpent-3-yl tridecyl ester (RT - 29.6) were also found.

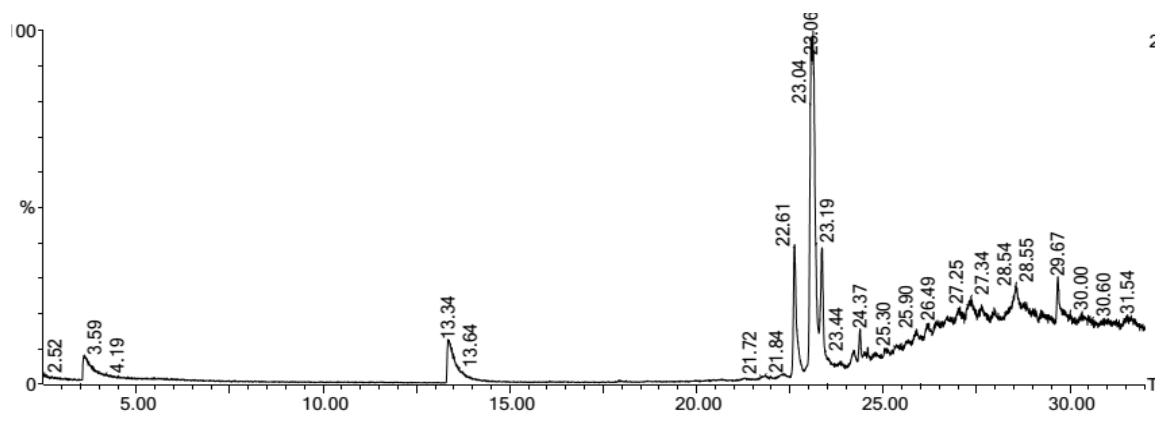

Figure 5. GC-MS analysis of pigment.

\subsection{Enzyme optimization.}

The optimum amylase was produced at a starch concentration of $0.8 \mathrm{~g}$ at $72 \mathrm{~h}$ at $40{ }^{\circ} \mathrm{C}$ in $\mathrm{pH} 5$ at $10 \% \mathrm{NaCl}$ concentration. (Figure 6-9). Amylase production was nil in the absence of sodium chloride; this indicated the halophilic nature of the enzyme production and activity. Similar behavior has been described by Deutch (2002) [43]. Marine Streptomyces sp. D1 was reported to produce amylase in a temperature range between 37 and $55{ }^{\circ} \mathrm{C}$ in 7 days [44].

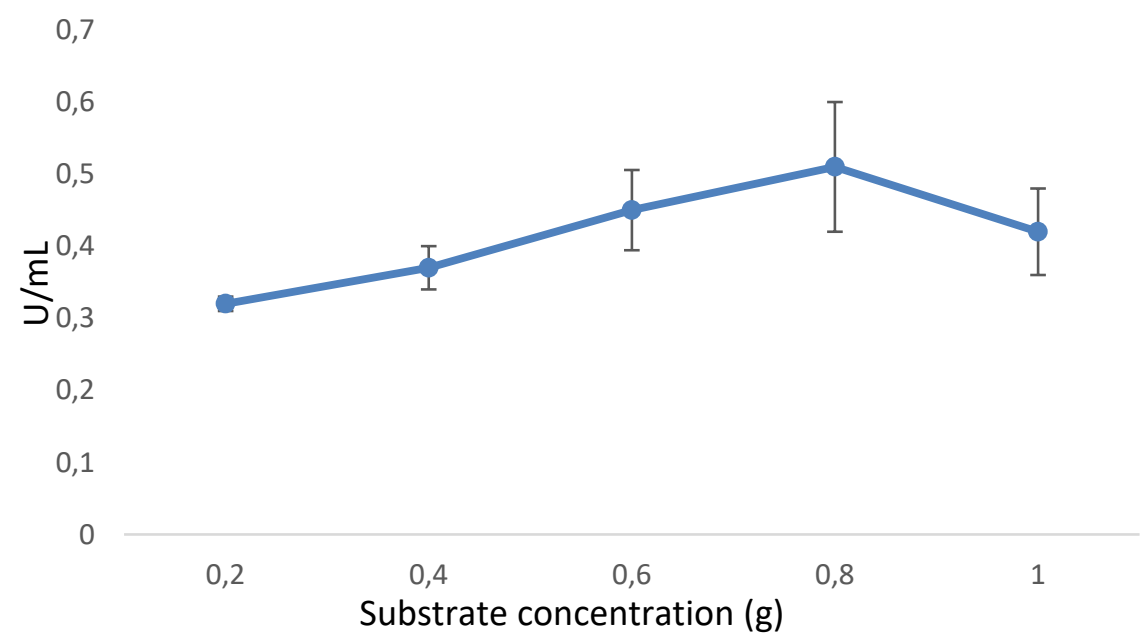

Figure 6. Optimization of substrate concentration for amylase production.

\subsection{Characterization of amylase}

The isolated amylase was found to have optimal activity at $40{ }^{\circ} \mathrm{C}$ and $\mathrm{pH} 5$ (results not shown). Most salt lakes are found to be with alkaline pH. Anupama and Jayaraman (2011) have isolated halotolerant $\alpha$-amylase from Bacillus aquimaris VITP4 stated that optimal activity in the $\mathrm{pH}$ range of $7.5-9.5$ at $40{ }^{\circ} \mathrm{C}$ [45]. Al-ZaZaee et al. (2011) isolated $\alpha$-Amylase from Halophilic Bacillus cereus Ms6 has maximum activity at $45{ }^{\circ} \mathrm{C}$ and $\mathrm{pH} 7.0$ [46]. 


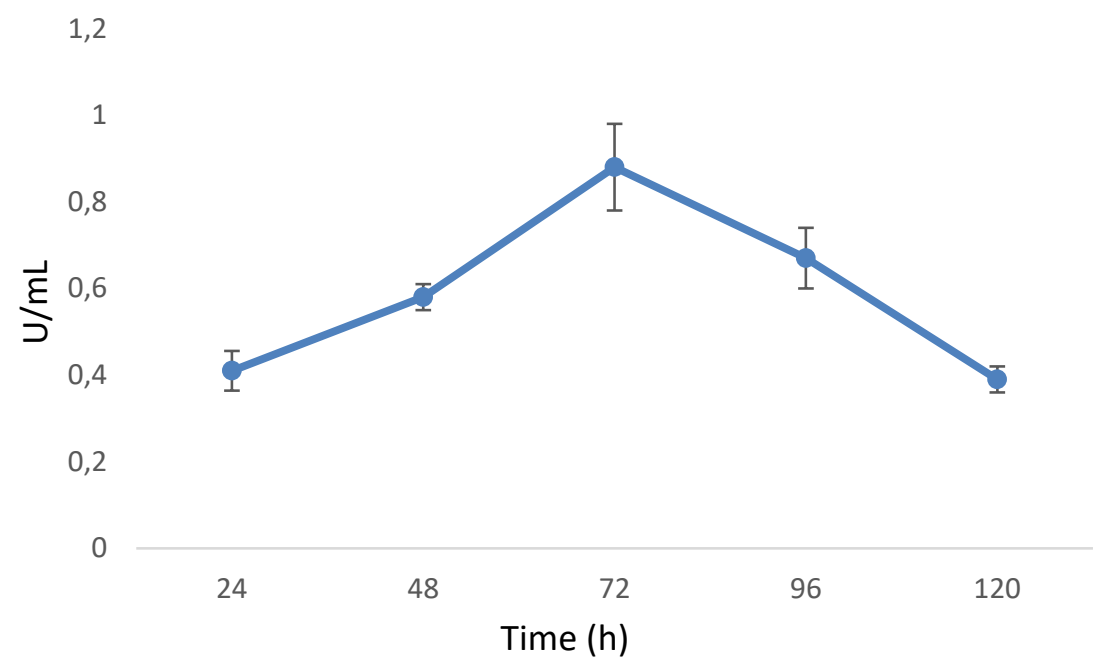

Figure 7. Optimization of time for amylase production.

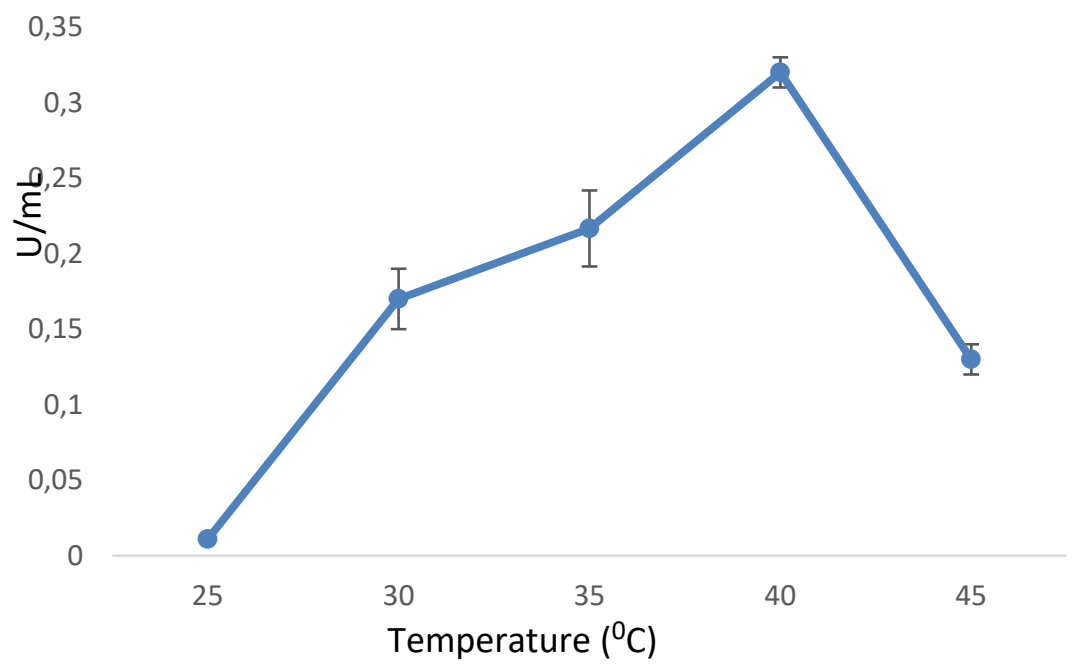

Figure 8. Optimization of temperature for amylase production.

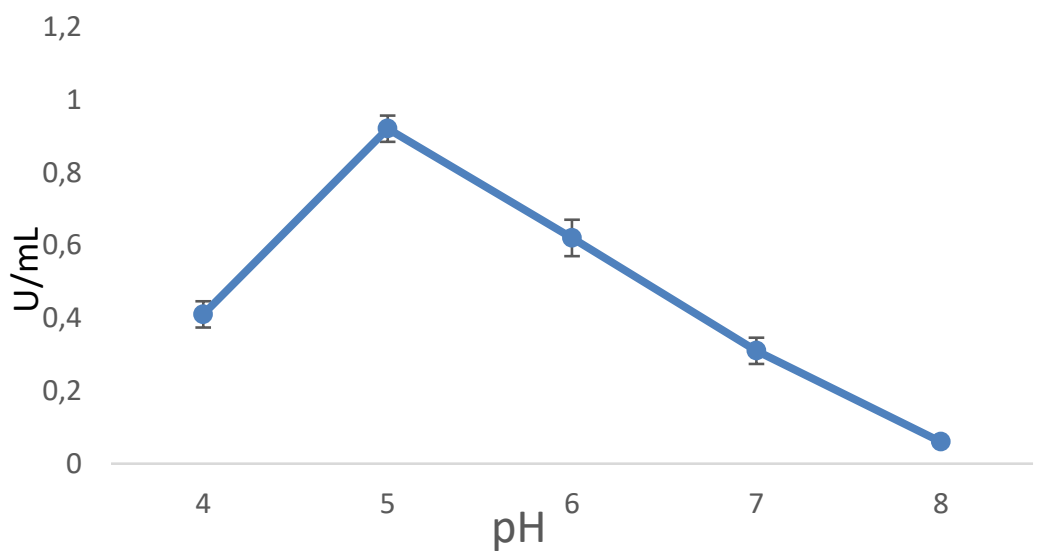

Figure 9. Optimization of $\mathrm{pH}$ for amylase production.

\subsection{Antimicrobial susceptibility study.}

Antibacterial susceptibility test for pigment was done against two pathogenic microorganisms - Escherichia coli and Staphylococcus aureus. There was no significant antibacterial potential shown by the pigment, whereas the Streptomyces sp MA05 extract showed activity at $100 \mu \mathrm{g}$ concentration against Escherichia coli. (Table 6). Halophilic bacteria 
isolated from Ratnagiri coastal area, Maharashtra, India showed antibacterial activity against Gram-negative bacteria like E. coli, Pseudomonas aeruginosa, Klebsiella pneumoniae, and Gram-positive bacteria - Bacillus subtilis [47]. Moderate halophilic Streptoverticillium of Bejaia [48] showed antibacterial activity against six pathogenic organisms.

Table 6. Antimicrobial activity of pigment and extract.

\begin{tabular}{|c|c|c|c|c|c|c|c|c|c|}
\hline \multirow[t]{3}{*}{ S.no } & \multirow[t]{3}{*}{ Source } & \multicolumn{8}{|c|}{ Zone of inhibition (mm) } \\
\hline & & \multicolumn{4}{|c|}{ Pigment } & \multicolumn{4}{|c|}{ Streptomyces sp MA05 extract } \\
\hline & & 25 & 50 & 75 & 100 & 25 & 50 & 75 & 100 \\
\hline 1. & E.coli & - & - & - & - & - & - & - & + \\
\hline 2. & S.aureus & - & - & - & - & - & - & - & - \\
\hline
\end{tabular}

- - no activity, + - showed activity

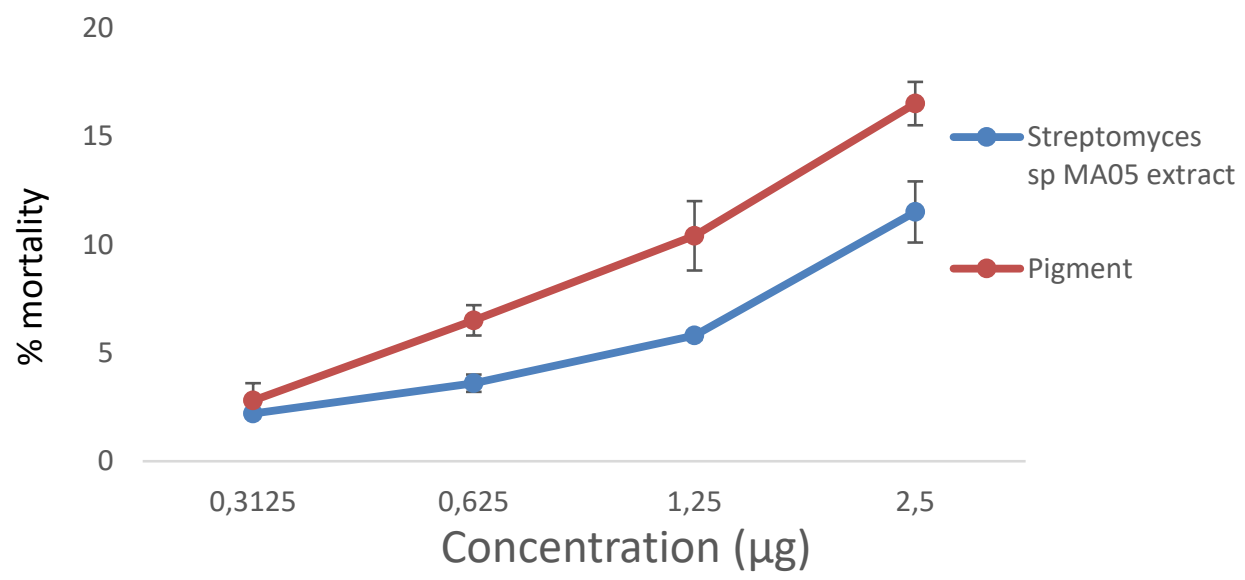

Figure 10. Cytotoxicity of Streptomyces sp MA05 extract and pigment against VERO cell lines.

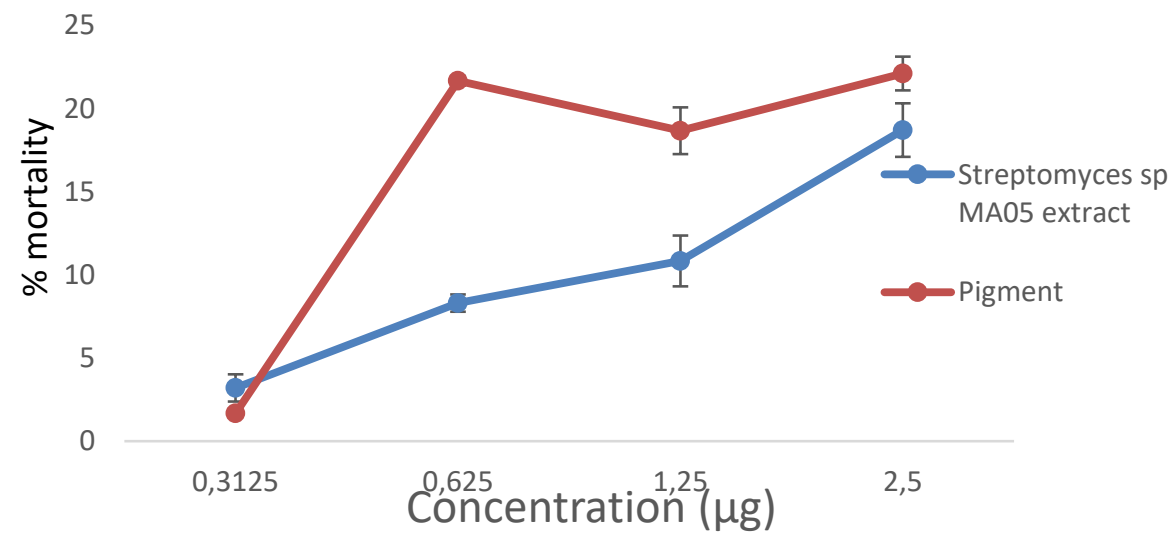

Figure 11. Cytotoxicity of Streptomyces sp MA05 extract and pigment against Hep G2 cell lines.

\subsection{Anticancer activity.}

There was no significant activity by pigment and Streptomyces sp MA05 extract against Hep G2 and Vero cell lines. (Fig 10 and 11). However, Abbes et al. (2013), who worked on pigment from Halobacterium halobium isolated from a Tunisian solar saltern, where the bacterial carotenoid extracts have inhibited Hep-G2 [49]. Sudha and Masilamani (2012) isolated bioactive metabolite producing Streptomyces avidinii strain SU4, which inhibited the proliferation of HepG2 cells [50]. In our study, both did not have the constituent, which has anticancer activity. 


\section{Conclusions}

Two organisms were chosen for this study, which was isolated from the salt lake of Chennai. One was orange pigmented - Halobacterium sp MA06, and the other was chalky white colony-forming - Streptomyces sp MA05. The growth condition for both the organisms was optimized. Pigment production was optimized, and the pigment was found not to have antibacterial and anticancer activity. The chloroform extract of Streptomyces sp MA05 was found to have antibacterial activity and also to produce amylase. Amylase production was optimized, and the amylase was characterized.

\section{Funding}

This research received no external funding.

\section{Acknowledgments}

This research has no acknowledgment.

\section{Conflicts of Interest}

The authors declare no conflict of interest.

\section{References}

1. Samrot A.V.; Vijay, A. A-Amylase activity of wild and mutant strains of Bacillus sp. The Internet J Microbiol 2008, 6 .

2. Samrot, A.V.; Chandana, K.; SenthilKumar, P.; Narendrakumar, G. Optimization of prodigiosin production by Serratia marcescens SU-10 and evaluation of its bioactivity. International Research Journal of Biotechnology 2011, 2, 128-133.

3. Samrot, A.V.; Thirunalasundari, T. Therapeutic effect of Oscillatoria willei - A marine cyanobacterium in mice exposed to cigarette smoke. Journal of Pharmacy Research 2010, 3, 2286-2290.

4. Samrot, A.V.; Thirunalasundari, T. Effect of Oscillatoria willei - a marine cyanobacterium on hydrazine induced toxicity. Malaysian Journal of Microbiology 2012, 8, 229-234, https://doi.org/10.21161/mjm.39912.

5. Corral, P.; Amoozegar, M.A.; Ventosa, A. Halophiles and Their Biomolecules: Recent Advances and Future Applications in Biomedicine. Marine Drugs 2020, 18, https://doi.org/10.3390/md18010033

6. McGenity, T.J.; Sorokin, D.Y. Methanogens and Methanogenesis in Hypersaline Environments. In: Biogenesis of Hydrocarbons. Stams, A.; Sousa D. (eds) Handbook of Hydrocarbon and Lipid Microbiology, Springer, Cham. 2019; https://doi.org/10.1007/978-3-319-78108-2_12.

7. Panosyan, H. Thermophilic and Halophilic Prokaryotes Isolated from Extreme Environments of Armenia and Their Biotechnological Potential. In: Microbial Versatility in Varied Environments. Singh, R.; Manchanda, G.; Maurya I.; Wei Y. (eds) Springer, Singapore. 2020; https://doi.org/10.1007/978981-15-3028-9_2

8. Samrot, A.V.; Shobana, N.; Kumar, S.S.; Narendrakumar, G. Production, optimization and characterisation of chitosanase of Bacillus sp and its applications in nanotechnology. Journal of Cluster Science 2019, 30, 607-620, https://doi.org/10.1007/s10876-019-01520-z.

9. Singh, P.; Jain, K.; Desai, C.; Tiwari, O.; Madamwar, D. Microbial community dynamics of extremophiles/extreme environment. In: Microbial Diversity in the Genomic Era, Academic Press, 2019; pp. 323-332, https://doi.org/10.1016/B978-0-12-814849-5.00018-6.

10. Seck, E.H.; Dufour, J.C.; Raoult, D.; Lagier, J.C. Halophilic \& halotolerant prokaryotes in humans. Future Microbiology 2018, 13, 799-812, https://doi.org/10.2217/fmb-2017-0237.

11. Amoozegar, M.A.; Safarpour, A.; Akbari Noghabi, K.; Bakhtiary, T.; Ventosa, A. Halophiles and their vast potential in biofuel production. Frontiers in microbiology 2019, 10, https://doi.org/10.3389/fmicb.2019.01895.

12. Menasaria, T.; Aguilera, M.; Hocine, H.; Bennammar, L.; Ayachi, A.; Bachir, A.S.; Dekak, A.; MonteolivaSanchez, M. Diversity and bioprospecting of extremely halophilic archaea isolated from Algerian arid and semi-arid wetland ecosystems for halophilic-active hydrolytic enzymes. Microbiological Research 2018, 207, 289-298, https://doi.org/10.1016/j.micres.2017.12.011. 
13. Cira-Chávez, L.A.; Guevara-Luna, J.; Soto-Padilla, M.Y.; Román-Ponce, B.; Vásquez-Murrieta, M.S.; Estrada-Alvarado, M.I. Kinetics of Halophilic Enzymes. In: Kinetics of Enzymatic Synthesis. IntechOpen. 2018; http://dx.doi.org/10.5772/intechopen.81100.

14. Jin, M.; Gai, Y.; Guo, X.; Hou, Y.; Zeng, R. Properties and applications of extremozymes from deep-sea extremophilic microorganisms: A mini review. Mar. Drugs 2019, 17, https://doi.org/10.3390/md17120656.

15. Ibrahim, I.M.; Konnova, S.A.; Sigida, E.N.; Lyubun, E.V.; Muratova, A.Y.; Fedonenko, Y.P.; Elbanna, K. Bioremediation potential of a halophilic Halobacillus sp. strain, EG1HP4QL: exopolysaccharide production, crude oil degradation, and heavy metal tolerance. Extremophiles 2020, 24, 157-166, https://doi.org/10.1007/s00792-019-01143-2.

16. Zhu, D.; Adebisi, W.A.; Ahmad, F.; Sethupathy, S.; Danso, B.; Sun, J. Recent development of Extremophilic Bacteria and Their Application in Biorefinery. Frontiers in Bioengineering and Biotechnology 2020, 8 , https://doi.org/10.3389/fbioe.2020.00483.

17. Deepalaxmi, R. K; Gayathri, C. Screening of bioactive compound, antimicrobial activity producing halophilic isolates from the saltpans of Thoothukudi district. African Journal of Microbiology Research 2018, 12, 338-344, https://doi.org/10.5897/AJMR2018.8823.

18. Başaran, T.I.; Berber, D.; Gökalsın, B.; Tramice, A.; Tommonaro, G.; Abbamondi, G.R.; Erginer Hasköylü, M.; Toksoy Öner, E.; Iodice, C.; Sesal, N.C. Extremophilic Natrinema versiforme Against Pseudomonas aeruginosa Quorum Sensing and Biofilm. Frontiers in microbiology 2020, 11, https://doi.org/10.3389/fmicb.2020.00079.

19. Yadav, A.N.; Kour, D.; Rana, K.L.; Yadav, N.; Singh, B.; Chauhan, V.S.; Rastegari, A.A.; Hesham, A.E.L.; Gupta, V.K. Metabolic engineering to synthetic biology of secondary metabolites production. In: New and Future Developments in Microbial Biotechnology and Bioengineering. Elsevier, 2019; pp. 279-320, https://doi.org/10.1016/B978-0-444-63504-4.00020-7.

20. Conde-Martínez, N.; Acosta-González, A.; Díaz, L.E.; Tello, E. Use of a mixed culture strategy to isolate halophilic bacteria with antibacterial and cytotoxic activity from the Manaure solar saltern in Colombia. BMC Microbiol 2017, 17, https://doi.org/10.1186/s12866-017-1136-x.

21. Giani, M.; Garbayo, I.; Vílchez, C.; Martínez-Espinosa, R.M. Haloarchaeal carotenoids: healthy novel compounds from extreme environments. Marine drugs 2019, 17, https://doi.org/10.3390/md17090524.

22. Manjula, D.; Jeevitha, P.; Ramya, I.; Hemapriya, J.; Ravi, A. Biotechnological Applications of Halophilic Pigments-An Overview. International Journal of Current Microbiology and Applied Sciences 2018, 7 , 4392-4398, https://doi.org/10.20546/ijcmas.2018.707.512.

23. Kumar, V; Tiwari, S.K. Halocin diversity among Halophilic Archaea and their applications. In: Microbial diversity in ecosystem sustainability and biotechnological applications. Springer, Singapore. 2019; pp. 497532, https://doi.org/10.1007/978-981-13-8315-1_16.

24. Manikandan, M.; Pasić, L.; Kannan, V. Optimization of growth media for obtaining high-cell density cultures of halophilic archaea (family Halobacteriaceae) by response surface methodology. Bioresource Technology 2009, 100, 3107-12, https://doi.org/10.1016/j.biortech.2009.01.033.

25. Mironescu, M.; Mironescu, I.D.; Jascanu V.; Posten, C. Influence of cultivation media on halobacteria I. Growth and biomass formation. Acta Universitatis Cibiniensis 2003, 7, 17-24.

26. Kelly, M.; Norgard, S.; Liaasen-Jensen, S. Bacterial carotenoids. XXXI. C50-carotenoids 5. Carotenoids of Halobacterium salinarum, especially, bacterioruberin. Acta Chemica Scandinavica 1970, 24, 2169-2182, https://doi.org/10.3891/acta.chem.scand.24-2169.

27. Samrot, A.V.; Rio, A.J.; Kumar, S.S.; Samanvitha, V. Bioprospecting studies of pigmenting Pseudomonas aeruginosa SU-1, Microvirga aerilata SU14 and Bacillus megaterium SU15 isolated from garden soil. Biocatalysis Agricultural Biotechnology 2017, 11, 330-337, https://doi.org/10.1016/j.bcab.2017.08.003.

28. Cordeiro, C.A.M.; Martins, M.L.L.; Luciano, A.B. Production and properties of a-amylase from thermophilic Bacillus sp. The Brazilian Journal of Microbiology 2002, 33, 57-61, http://dx.doi.org/10.1590/S1517-83822002000100012.

29. Miller, G.L. Use of Dinitrosalicylic Acid Reagent for Determination of Reducing Sugar. Analytical Chemistry 1959, 31, 426-428, https://doi.org/10.1021/ac60147a030.

30. Bernfeld, P. Amylase a and b. Methods in Enzymology 1955, 1, 149-158, https://doi.org/10.1016/00766879(55)01021-5.

31. Samrot, A.V.; Prasad, R.J.J.; Rio, A.J.; Sneha, S.J. Bioprospecting of Brevibacillus brevis isolated from soil. Recent Patents on Biotechnology 2015, 9, 42-9, https://doi.org/10.2174/187220830901151111124333.

32. Gebreyohannes, G.; Moges, F.; Sahile, S.; Raja, N. Isolation and characterization of potential antibiotic producing actinomycetes from water and sediments of Lake Tana, Ethiopia. Asian Pacific Journal of Tropical Biomedicine 2013, 3, 426-35, https://doi.org/10.1016/S2221-1691(13)60092-1.

33. Mosmann, T. Rapid colorimetric assay for cellular growth and survival: Application to proliferation and cytotoxicity assays. The Journal of Immunological Methods 1983, 65, 55-63, https://doi.org/10.1016/00221759(83)90303-4. 
34. Hongyu, W.; Yang, L.; Shen, L.; Hu, B.; Zongyun, L.; Qijiang, J. Isolation and characterization of culturable halophilic microorganisms of salt ponds in Lianyungang, China. World Journal of Microbiology and Biotechnology 2009, 25, 1727-1732, https://doi.org/10.1007/s11274-009-0068-5.

35. Roohi, A.; Ahmed, I.; Iqbal M.; Jamil, M. Preliminary isolation and characterization of halotolerant and halophilic bacteria from salt mines of Karak. Pakistan Journal of Botany 2012, 44, 365-370.

36. Yildiz, E.; Ozcan, B.; Caliskan, M. Isolation, characterization and phylogenetic analysis of halophilic archaea from a salt mine in central Anatolia (Turkey). Polish Journal of Microbiology 2012, 61, 111-7, https://doi.org/10.33073/pjm-2012-014.

37. Grant, W.D.; Kamekura, M.; McGenity, T.J.; Ventosa. A. Class III. Halobacteria class. nov. In: In: Bergey's manual of systematic bacteriology. Boone, D.R.; Castenholz, R.W.; Garrity, G.M. editors.2nd edn Volume 1. Springer Verlag; New York: 2001; pp. 294-301.

38. Mironescu, M.; Oprean, L.; Jâşcanu, V. Optimisation of cultivation media composition for biomass production by haloarchaea using response surface methodology, Proceedings of the International Conference: Agricultural and Food Sciences, Processes and Technologies, Section Biotechnologies, Sibiu. 2005; pp. 281-288.

39. Alinei, R.; Ionica, A.; Cheratoiu, C.; Cicu, M.; Gheorghita, D.; Guzu, D.; Falamas, R.; Bucurenciu, C.; Arimie, B.; Mironescu, M.; Oprean L. Isolation of halophylic microorganisms in the saline lakes from Ocna sibiului and analysis of red pigments production. Acta Universitatis Cibiniensis Series E: Food Technology 2006, $X / 2,21-33$.

40. Khanafari, A.; Khavarinejad, D.; Mashinchian, A. Solar salt lake as natural environmental source for extraction halophilic pigments. Iranian Journal of Microbiology 2010, 2, 103-109.

41. Silva-Castro, G.A.; Moyo, A.C.; Khumalo, L.; Zyl, L.J.V.; Petrik, L.F.; Trindade, M. Factors influencing pigment production by halophilic bacteria and its effect on brine evaporation rates. Microbial Biotechnology 2019, 12, 334-345, https://doi.org/10.1111/1751-7915.13319.

42. Costantino, L.; Parenti, C.; Di Bella, M.; Zanoli, P.; Baraldi, M. Anti-Inflammatory Activity of Newly Synthesized 2,6-bis-(1,1-Dimethylethyl) Phenol Derivatives. Pharmacological Research 1993, 27, 349-358, https://doi.org/10.1006/phrs.1993.1034.

43. Deutch, C.E. Characterization of a salt-tolerant extracellular a-amylase from Bacillus dipsosauri. Letters in Applied Microbiology 2002, 35, 78-84, https://doi.org/10.1046/j.1472-765X.2002.01142.x.

44. Chakraborty, S.; Khopade, A.; Kokare, C.; Mahadik, K.; Chopade, B. Isolation and characterization of novel $\alpha$-amylase from marine Streptomyces sp. D1. Journal of Molecular Catalysis B: Enzymatic 2009, 58, 17-23, https://doi.org/10.1016/j.molcatb.2008.10.011.

45. Anupama, A.; Jayaraman, G. Detergent stable, halotolerant $\alpha$-amylase from Bacillus aquimaris vitp4 exhibits reversible unfolding. International Journal of Applied Biology and Pharmaceutical Technology 2011, 2, 366-376.

46. Al-ZaZaee, M.M.A.; Neelgund, S.; Gurumurthy, D.M.; Rajeshwara, A.N. Identification, Characterization of Novel Halophilic Bacillus cereus Ms6: a Source for Extra Cellular A-Amylase. Advances in Environmental Biology 2011, 5, 992-999.

47. Todkar, S.; Todkar, R.; Kowale, L.; Karmarkar, K.; Kulkarni, A. Isolation and Screening of Antibiotic producing Halophiles from Ratnagri coastal area, State of Maharahstra. International Journal of Scientific and Research Publications 2012, 2, 2250-3153.

48. Djinni, I.; Kecha, M.; Souagui, S.; Said, B. Antimicrobial activity of a moderate halophilic actinomycete strain isolated from saline soil in the region of Bejaia :Extraction: and partial characterisation of the produced bioactive compounds. Conference: Environmental Engineering and Management Journal 2012, 11, S82.

49. Abbes, M.; Baati, H.; Guermazi, S.; Messina, C.; Santulli, A.; Gharsallah, N.; Ammar, E. Biological properties of carotenoids extracted from Ha lobacterium halobium isolated from a Tunisian solar saltern. BMC Complementary Medicine and Therapies 2013, 13, https://doi.org/10.1186/1472-6882-13-255.

50. Sudha, S.; Masilamani, S.M. Characterization of cytotoxic compound from marine sediment derived actinomycete Streptomyces avidinii strain SU4. Asian Pacific Journal of Tropical Biomedicine 2012, 2, 7703, https://doi.org/10.1016/S2221-1691(12)60227-5. 